Обзор литературы

УДК 336.74

doi: $10.17586 / 2713-1874-2021-1-26-31$

\title{
A CONTEMPORARY LITERATURE REVIEW OF THE RUSSIAN ROUBLE DETERMINANTS
}

\section{Morad Bali}

Institut de recherche sur la Résolution Non-violente des Conflits, Montreuil, France, morad.bali@irnc.org Article in English

\begin{abstract}
This short literature review's goal is to examine available papers regarding the study of Russian Rouble determinants. For purpose of analysis, 35 articles were studied among which 22 were selected, for a total of 414 pages shelled. This work analyzes most recent empirical articles, in order to identify factors responsible for the Russian currency fluctuations. Different models will be compared to learn if some are more effective than others, from basic Linear regression to Structural vector autoregressive, through Ordinary least squares or Vector error correction models. Moreover, a very special and particular attention will be paid to variables used. Which combinations of variables are used to study factors influencing the Russian currency? While it seems vital to include oil prices, interest rate, and consumer price index, is it important to have them all together in the same model? Are results among papers similar? In addition, would it be necessary to add variables such as GDP, gold price, gas price, M2 aggregate or sanctions? However, this paper will compare data from each model and try to find out if there is one best way to study the Russian currency determinants.
\end{abstract}

Keywords: Russian ruble, linear regression model, VAR, VEC

For citation: Bali M. A Contemporary Literature Review of the Russian Rouble Determinants. Ekonomika. Pravo. Innovacii. 2021. No.1. pp. 26-31. http://dx.doi.org/10.17586/2713-1874-2021-1-26-31.

\section{ДЕТЕРМИНАНТЫ УРОВНЯ ОБМЕННОГО КУРСА РОССИЙСКОГО РУБЛЯ: ОБЗОР СОВРЕМЕННОЙ ЛИТЕРАТУРЫ}

\section{Морад Бали}

Институт исследований ненасильственного разрешения конфликтов, Монтрей, Франция, morad.bali@irnc.org Язык статьи - английский

Аннотация: Целью данного обзора литературы является исследование научных публикаций и других источников, касающихся изучения детерминант уровня обменного курса российского рубля. Для анализа было изучено 35 статей, из которых были отобраны двадцать две, общий объем составил 414 страниц. В данной работе были проанализированы актуальные эмпирические статьи с целью выявления факторов, определяющих колебания курса российского рубля. Был проведен анализ различных моделей, ряд которых наиболее эффективен для анализа: от базовой линейной регрессии до структурной векторной авторегрессии, через обычные наименьшие квадраты или модели коррекции векторных ошибок. В работе были изучены проблемы: какие комбинации переменных используются для изучения факторов, влияющих на российскую валюту; важно ли учитывать цены на нефть, процентную ставку и индекс потребительских цен; целесообразно ли рассматривать их все вместе в одной модели;получены ли сходные результаты в других исследованиях; необходимо ли добавлять такие переменные, как ВВП, цена на золото, цена на газ, агрегат М2 или санкции. В данной работе проведено сравнение данных каждой модели и сделана попытка выяснить, существует ли один наилучший способ изучения детерминант курса российской валюты.

Ключевые слова: российский рубль, модель линейной регрессии, VAR-модель, VEC-модель

Ссылка для цитирования: Bali M.A Contemporary Literature Review of the Russian Rouble Determinants (на англ.) // Экономика. Право. Инновации. 2021. № 1. С. 26-31. http://dx.doi.org/10.17586/2713-1874-2021-1-26-31. 
Introduction. Over the recent period, the Russian rouble has been subjected to numerous speculations and fantasies. The currency of the Russian Federation made the news in an unprecedented fashion. Indeed, the Ukrainian crisis marked a turning point in the currency's behaviour. Whereas it was possible to buy one U.S. dollar (more or less) with 30 roubles in January 2014, it was necessary to give twice as many to get one dollar a year later. The media didn't need more to justify this depreciation with international sanctions, swearing that the Russian economy was collapsing under Western pressure. Yet, even if it is true that sanctions started roughly at the same period, several other exogenous factors also happened. Among them, capital flight and oil price fall were great candidates to explain the rouble weakening. However, it is also important to bear in mind that the Russian currency depends on endogenous factors such as M2 aggregate, Central Bank key interest rates et cetera.

The Russian rouble is the currency of the Russian Federation. It was introduced in 1992 to replace the Soviet rouble, itself introduced in 1923, see [1]. It is also the first currency to have been decimalised under Tsar Peter the Great in 1704 with one rouble being equal to one hundred kopeks. Moreover, after the British pound, the rouble is the oldest national currency, and has been used in Russian territories since the $13^{\text {th }}$ century, see [2]. Nowadays, one might like to know that the Russian currency is also used in Donetsk People's Republic, Luhansk People's Republic, Republic of Abkhazia and Republic of South Ossetia. The aim of this paper is to examine the available literature regarding the Russian currency's determinants, in order to provide an up-to-date synthesis. To do so, the first part of this work will study research papers using linear regression models, while the second part will focus on vector-based models.

Basic Linear Regression Models. In this part we will try to find common points and differences between papers studying the rouble, comparing both data and results of the literature.

Data. Six papers using linear regression models have been reviewed, among which some interesting trends can be gleaned. Most of them integrate oil prices, revealing the importance of Brent fluctuations. The only paper that isn't using oil prices is the one of [3] since it uses gas and focuses mostly on Consumer Price Index (CPI) and Gross Domestic Product (GDP). It seems that half papers are using real effective exchange rate, while others are using nominal exchange rate. Finally, if consumer price index is integrated in most papers, M2 aggregate is used in only two of them. Surprisingly, sanctions aren't present in every model, even in most recent ones. However, it seems that linear regression models studying the Russian currency are using four variables in their calculations on average. See Table 1 for further details.

Table 1

\section{Different variables used in basic linear regression models}

\begin{tabular}{|c|c|c|c|c|c|c|c|c|}
\hline Author(s) & Model & Rub or \$ & Oil & Interest rate & Sanctions & CPI & GDP & M2 \\
\hline$[3]$ & OLS & REER & Y & Money Market & $\mathrm{N}$ & $\mathrm{Y}$ & $\mathrm{Y}$ & $\mathrm{N}$ \\
\hline$[4]$ & OLS & REER & $\mathrm{Y}$ & $\mathrm{Y}$ & Dummy & $\mathrm{Y}$ & $\mathrm{N}$ & $\mathrm{N}$ \\
\hline$[5]$ & Linear & REER & $\mathrm{Y}$ & $\mathrm{N}$ & $\mathrm{N}$ & $\mathrm{Y}$ & $\mathrm{N}$ & $\mathrm{N}$ \\
\hline$[13]$ & Distributed lag models & NOMINAL & $\mathrm{N}$ & $\mathrm{N}$ & $\mathrm{N}$ & $\mathrm{Y}$ & $\mathrm{REAL}$ & $\mathrm{Y}$ \\
\hline$[19]$ & ADL & $\mathrm{Y}$ & $\mathrm{Y}$ & $\mathrm{N}$ & $\mathrm{N}$ & $\mathrm{N}$ & $\mathrm{N}$ & $\mathrm{Y}$ \\
\hline$[20]$ & Autoregressive & NOMINAL & $\mathrm{Y}$ & MIOIR & $\mathrm{N}$ & $\mathrm{N}$ & $\mathrm{N}$ & $\mathrm{N}$ \\
\hline
\end{tabular}

Notes: " $Y$ " stands for "yes" and means that the variable is used in the paper, while "N" stands for "no" and means

that the variable is not integrated in the model. In [4] these variables are also integrated: gas, gold, stocks, euro against U.S. dollar exchange rate. In [3], regulated rates charged for electric power, gas, and railroad transportation are also integrated. 
Results. In light of the above, [4] is using most variables in his model (seven in total). For which results? Firstly, a decline in oil price leads to the Russian rouble depreciation. Additionally, it also seems that a U.S. dollar appreciation triggers a rouble depreciation. Finally, price of natural gas doesn't have an explanatory power, and can be excluded as a determinant of the Russian currency. More recently, the paper of [5] is using a total of five variables, in which sanctions are set as a dummy variable. A new key result is that inflation in the domestic market leads to a devaluation of the rouble. Moreover, because of sanctions and the fact that Russian companies had debt in USD, the demand for USD has grown in Russia, leading to a depreciation of the rouble (from $35 \mathrm{rub} / \mathrm{USD}$ to 65 $\mathrm{rub} / \mathrm{USD}$ ). It should be noted that it follows findings of [4].

Finally, another important result is that a rise in Central Bank key interest rates increases the Rouble demand and strengthens it. It mostly increases the offer of foreign currency and reduces the dollar cost. In another fashion, [6] are also using four variables in their model. They are among the two papers of this section integrating the GDP in their calculations. Their results show that a lower oil price leads to a real depreciation of the rouble in addition to slowing down economic growth. Reversely, they find that a high oil price leads to a nominal appreciation of the rouble, and to higher inflation.

On the basis of a seven variables model, [3] found interesting results regarding the relationship between consumer price index and Russian rouble. Oppositely to [6], it seems that an appreciation of the Russian currency leads to a decrease of inflation and vice versa. Thus, a $1 \%$ appreciation of the rouble leads to a $0.1 \%$ decrease of inflation. Yet, a $1 \%$ depreciation of the rouble brings an increase of inflation of $0.2 \%$. In other words, consumer price index responds more readily to a depreciation than to an appreciation of the Russian currency. Besides, if the model is run without the monetary supply variable, the estimated exchange rate coefficient decreases. Moreover, a stimulating monetary policy causes a drop in the Russian rouble. Meaning that monetary policy is endogenous in relation to the rouble, as demonstrated by previous studies, see [7]. Using a three variables model, [8] get interested in effects induced by the switch to a floating exchange rate of rouble in November 2015. They found that this switch has softened the negative effect of oil price variations. Indeed, they state that the rouble became less sensitive to a decrease in oil price. More interestingly, they explain that the influence of endogenous factors on exchange rate of rouble is increasing with the decline of oil price. Finally, regarding the consumer price index, they suggest that an oil price below $\$ 10-15$ per barrel could be critical for the Russian economy, a trigger in hyperinflation.

The last paper that has been reviewed is the one of [9], it is also a model based on three variables. They aspire to get interested in the impact of sanctions on the Russian economy, but it is not clear how they simulate sanctions in their models. However, they confirm previous results since they find that a decrease in oil prices of $\$ 1$ depreciate the Russian currency by $\$ 0.58$ in average.

Vector-Based Models (VEC, VAR). In this section, papers using vector-based models are considered. The great majority of articles reviewed are using Vector Auto Regression models (VAR). These models have solid forecasting capabilities, and can easily be tested for Granger non-causality. However, the major advantage that can be found in these models - in comparison with linear regression ones - is related to their specification. Indeed, researchers can somehow get rid of the theory bias, as they don't need to assess which variables of the model are endogenous or exogenous since they are all endogenous. Some would say that the ability of VAR to avoid economic theory and economic assumptions is a handicap; but in a world full of uncertainty, more credence could be put in the fact that these models can free ourselves from subjective and coercive political constraints. It doesn't matter if the researcher is either liberal or socialist, since his own personal beliefs are less likely to influence his model construction, and thence his results. However, since it is also important to compare results depending on the model used, this section will focus on nine papers, using two to seven variables. 
Table 2

Different Variables Used In Vector-Based models

\begin{tabular}{|c|c|c|c|c|c|c|c|c|}
\hline Author(s) & Model & RUB/USD & Oil & Interest rate & Sanctions & CPI & GDP & M2 \\
\hline$[2]$ & VECM & REER & $\mathrm{Y}$ & $\mathrm{N}$ & $\mathrm{N}$ & $\mathrm{N}$ & REAL & $\mathrm{Y}$ \\
\hline$[7]$ & VAR & NOMINAL & $\mathrm{Y}$ & RUONIA & Index & $\mathrm{N}$ & $\mathrm{N}$ & $\mathrm{N}$ \\
\hline$[10]$ & VAR & NOMINAL & $\mathrm{N}$ & REFRATEM & $\mathrm{N}$ & $\mathrm{Y}$ & $\mathrm{N}$ & $\mathrm{Y}$ \\
\hline$[12]$ & VAR & REER & $\mathrm{Y}$ & $\mathrm{N}$ & $\mathrm{N}$ & $\mathrm{Y}$ & $\mathrm{IPI}$ & $\mathrm{N}$ \\
\hline$[13]$ & VAR & REER & $\mathrm{Y}$ & $\mathrm{N}$ & $\mathrm{N}$ & $\mathrm{Y}$ & $\mathrm{REAL}$ & $\mathrm{Y}$ \\
\hline$[14]$ & VEC & REER & $\mathrm{Y}$ & $\mathrm{N}$ & $\mathrm{N}$ & $\mathrm{N}$ & $\mathrm{N}$ & $\mathrm{N}$ \\
\hline$[16]$ & VAR \& VECM & REER & $\mathrm{Y}$ & $\mathrm{N}$ & $\mathrm{N}$ & $\mathrm{N}$ & $\mathrm{Y}$ & $\mathrm{Y}$ \\
\hline$[18]$ & $\mathrm{VAR}$ & REER & $\mathrm{Y}$ & $\mathrm{N}$ & $\mathrm{Dummy}$ & $\mathrm{Y}$ & $\mathrm{REAL}$ & $\mathrm{N}$ \\
\hline$[21]$ & VAR & $\mathrm{Y}$ & $\mathrm{Y}$ & $\mathrm{Y}$ & $\mathrm{N}$ & $\mathrm{Y}$ & $\mathrm{Y}$ & $\mathrm{Y}$ \\
\hline
\end{tabular}

Notes: "Y" stands for "yes" and means that the variable is used in the paper, while " $N$ " stands for "no" and means that the variable is not integrated in their model. In [10] these variables are also integrated: Real household consumption expenditure, Real government consumption expenditure, Real investment, Real exports and real imports. In [11], physical volume of exported oil, differential in labour productivity of Russia vs its trade partners, government expenditures, and net international reserves are also included.

Data. Nine papers using vector-based models have been reviewed. This is three more than the previous section. Here again, they are all integrating oil prices, except the paper of [12]. On the one hand, gross domestic product is used in most papers as much as consumer price index (CPI) and M2 aggregate (used in five articles). On the other hand, interest rate can be found in three papers, and sanctions in only two - even if five papers use data covering the implementation of economic sanctions. Unlike basic linear regression models, more than half of the studied literature is using real effective exchange rate. Finally, half of these papers use more than four variables.

Results. It seems rational to begin with [13] since their paper has the most complete model with six variables in total. Their study focuses on the relationship between Russian rouble and energy prices. They find that when international energy price index rises, exchange rate appreciates. Moreover, they state that $41.1 \%$ of the Russian currency fluctuation is due to changes in energy prices. They also find that $26 \%$ of the rouble fluctuation is explained by weighted annual interest rates. It strengthens the fact that interest rates are an important variable to study the Russian exchange rate. Another paper using a quite complete VAR model - 10 variables based - is the one of [10]. From the rouble perspective, there is nothing new under the sun as their Impulse-Response figures confirm that in the case of a drop in oil prices, the Russian currency increases in the short-term. Meaning that the rouble would depreciate in reaction to a decrease in oil prices. In the same way, [14] also found that the bulk of rouble's depreciation is caused by a decline in oil prices, and vice versa. Using four variables SVAR, they also found that an increase of Russian interbank rate for overnight loans (RUONIA) leads to an appreciation of the Russian currency, while a depreciation of the rouble causes an increase of RUONIA. Moreover, sanctions in their paper are simulated with a composite index, and results of impulse response functions reveal that the Russian rouble is quite robust against sanctions.

[11] confirmed that eruptive flows of export revenues (Oil Price) result in a significant appreciation of the real effective exchange rate. In addition, they put forward that an increase in export revenues by $1 \%$ causes a $0.2 \%$ appreciation of the rouble. This means that it is highly likely that the Russian currency is serving as a channel through which oil prices can affect the 
economic structure. Interestingly, [15] exposes the fact that in the short-term, economic development also plays a major role in the determination of the real effective exchange rate. Thus, it seems that a $10 \%$ increase (decrease) of the Russian rouble is related to a $0.5 \%$ appreciation (depreciation) of the economic activity in the long-term. [12] made some useful discoveries. Based on a four variables VAR model, they expose that an interest rate increase triggers a consequent appreciation of the nominal exchange rate. Furthermore, if it is true that the currency is significantly affecting consumer price index in the short-run, the converse is not.

Finally, three papers have results that lean against the wind. [16] - based on four variables VAR\&VECM models - states, «Movements of the real exchange rate are not affected by changes in oil prices», which is quite surprising if we remember previous results of the literature. Following this paper and using a four variables VECM model, [17] find several relevant results. Indeed, impulse response functions (IRF) reveal that if the rouble appreciates in the short-term after a rise in oil prices, the Russian currency seems to depreciate in the long-term in response to the same shock. This uncommon long-term relationship might be explained by the fact that confidence intervals of their IRF witness a lack of significance in the long-term. However, they also explain that the appreciation of the exchange rate is related to an increase in government consumption (through its positive impact on inflation). This means that government consumption might be an interesting variable to integrate in models studying Russian rouble determinants. Finally, [18] found - using a five variables VAR model - that a $1 \%$ increase (decrease) in oil prices leads to a $0.17 \%$ depreciation (appreciation) of the Russian currency, both in the short-term and long-term. It is once again quite surprising since the vast majority of papers previously studied provide different results.

Conclusion. Two sets of papers were studied in this literature review. The first one focused on articles using basic linear regression models, while the second one explored vectorbased publications. It is clear for most authors that a decline in oil prices results in a depreciation of the Russian rouble, and vice versa. Thus, on the basis of results previously examined, which variables should be considered in order to build a reliable econometric model? First of all, Central Bank interest rates since their increase provoke an appreciation of the rouble, see [12] and [14]. Secondly, M2 monetary aggregate shall be integrated as control variable since monetary policy is endogenous in relation to the rouble. Thirdly, it is also interesting to integrate the Russian government spending as its increase leads to an appreciation of the exchange rate, see [17]. Concerning economic sanctions, they shall be integrated as a causal variable only.

Furthermore, the $€ /$ USD exchange rate is an interesting control variable to add. Indeed, as a reminder, [4] and [5] found a causal relationship between an appreciation of the USD and a depreciation of the RUB; not to mention that a large part of the Russian economy is highly related to the American currency (debt in USD, foreign direct investments, et cetera). Finally, the integration of capital flight as a control variable should be encouraged. Indeed, capital flight, as it occurred during the Ukrainian crisis, can influence the Russian currency drastically, see [19]. Strangely, it seems that authors reviewed during this work have almost all forgotten to integrate capital flight in their calculations. Whereas papers studying the relationship between capital flight and exchange rate are numerous, as [20] or [21] did. That being said, it is not necessary to add inflation in the econometric modelling since it has more chances to be influenced by the exchange rate than reversely, see [6] and [3]. Thus, it remains optional, except if the chosen database contains a period where the rouble has been devaluated. Some other variables are optional and can be set aside, such as gold, real household consumption expenditures, international reserves et cetera.

It would seem desirable to study determinants of the Russian currency with a VectorBased model of seven variables. A structural vector auto regression model would offer great possibilities with the support of impulse response functions. It would integrate Russian government spending, economic sanctions, Russian interbank rate for overnight loans, M2 monetary aggregate, $€ /$ USD exchange rate, capital flight, and, of course, the Russian rouble exchange rate. At the time of concluding this report and to our best knowledge, such a modelling has never been done before. 


\section{References}

1. Samotesov A., Strelkovskaya A., Kazachkova D. The History of the Ruble Origin. ББК 72 П78. 2018. p. 44.

2. Foo C.-T. Currency at War: A Longer View Springer. Available at: https://link.springer.com/ chapter/10.1007/978-981-13-2841-1_1

3. Kataranova M. The Relationship Between the Exchange Rate and Inflation in Russia. Problems of Economic Transition. 2010. No. 3 (53). pp. 45-68.

4. Urbanovsky T .Factors Behind the Russian Ruble Depreciation. Procedia Economics and Finance. 2015. No. 26. pp. 242-248.

5. Blokhina T., Karpenko O., Guirinskiy A. The Relationship Between Oil Prices and Exchange Rate in Russia. International Journal of Energy Economics and Policy. 2016. No. 4 (6). pp. 721726.

6. Benedictow A., Fjærtoft D., Løfsnæs O. Oil Dependency of the Russian Economy: AnEconometric Analysis. Economic Modelling. 2013. No. 32. pp. 400-428.

7. Esanov A., Merkl C., Souza L.V. Monetary Policy Rules for Russia. Journal of Comparative Economics. 2005. No. 3 (33). pp. 484-499.

8. Bykau A., Ghodsi A., Nezhadhossein H. Impact of Oil Prices on Russian Ruble on Condition of Floating Exchange Rate Regime. The 5-th International Virtual Scientific Conference on Informatics and Management Sciences. March, 21-25. 2016. pp. $1-3$.

9. Tyll L., Pernica K., Arltová M. The Impact of Economic Sanctions on Russian Economy and the RUB/USD Exchange Rate. Journal of International Studies. 2018. No. 1 (11).

10. Tuzova Y., Qayum F. Global Oil Glut and Sanctions: The Impact on Putin's Russia. Energy Policy. 2016. (90). pp. 140-151.

11. Mironov V., Petronevich A. Discovering the Signs of Dutch Disease in Russia. Resources Policy. 2015. No. (46). pp. 97-112.

12. Granville B., Mallick S. Does Inflation or Currency Depreciation Drive Monetary Policy
inRussia? Research in International Business and Finance. 2006. No. 2 (20). pp. 163-179.

13. Yu Y., Wu M. The Impact of Russia's OilDominated Energy Economic Changes on the Exchange Rate of Russian Ruble-Chinese Renminbi European Scientific Journal. 2017.

14. Dreger C., Kholodilin K., Ulbricht D. and others. Between the Hammer and the Anvil: The Impact of Economic Sanctions and Oil Prices on Russia's Ruble. Journal of Comparative Economics. 2016. No. 2 (44). pp. 295-308.

15. Izatov A. The Role of Oil Prices, Real Effective Exchange Rate and Inflation in Economic Activity of Russia: An Empirical Investigation. Available at: https://mpra.ub.uni-muenchen.de/70735/

16. Rautava J. The Role of Oil Prices and the Real Exchange Rate in Russia's Economy - a Cointegration Approach. Journal of Comparative Economics. 2004. No. 2 (32). pp. 315-327.

17. Beck R., Kamps A., Mileva E. Long-term Growth Prospects for the Russian Economy. ECB Occasional Paper. 2007. No. 58.

18. Ito K. Economic Analysis Working Papers. The impact of oil price volatility on macroeconomic activity in Russia. Available at: https://www.researchgate.net/publication/46542010_ The_Impact_of_Oil_Price_Volatility_on_Macroeco nomic_Activity_in_Russia

19. Anton K. Exchange Rat eModeling: The Case of Ruble. Review of Business and Economics Studies. 2015. No. 3.

20. Calvo G.A., Leiderman L., Reinhart C.M. Capital Inflows and Real Exchange Rate Appreciation in Latin America: the Role of External Factors. Staff Papers. 1993. No. 1 (40). pp. 108-151. 21. Ndou E., Gumata N., Ncube M. Capital Flow Episodes and Real Economic Costs of Flow Episodes Springer. Available at: https://link.springer.com/chapter/10.1007/978-3319-62280-4_17 